\title{
PNeUmocystis JIROVECII COLONIZATION IN CHRONIC PULMONARY DISEASE
}

\author{
GUTIÉRREZ S.***, RESPALDIZA N.*****, CAMPANO E.*, MARTÍNEZ-RISQUEZ M.T.**, \\ CALDERÓN E.J. ${ }^{*, * * * * * * * *} \&$ DE LA HORRA C. ${ }^{*, * * * *}$
}

\section{Summary:}

Pneumocystis jirovecii causes pneumonia in immunosuppressed individuals. However, it has been reported the detection of low levels of Pneumocystis DNA in patients without signs and symptoms of pneumonia, which likely represents colonization. Several studies performed in animals models and in humans have demonstrated that Pneumocystis induces a local and a systemic response in the host. Since $P$. jirovecii colonization has been found in patients with chronic pulmonary diseases it has been suggested that $P$. jirovecii may play a role in the physiopathology and progression of those diseases. In this report we revise $P$. jirovecii colonization in different chronic pulmonary diseases such us, chronic obstructive pulmonary disease, interstitial lung diseases, cystic fibrosis and lung cancer.

KEY WORDS: Pneumocystis jirovecii, colonization, chronic pulmonary disease.

\section{INTRODUCTION}

$P$ neumocystis jirovecii (human-derived Pneumocystis) is an atypical opportunistic fungus with lung tropism and worldwide distribution that causes pneumonia in immunosuppressed individuals (Calderon et al., 2010). Although non-immunosuppressed patients rarely develop Pneumocystis pneumonia (PcP) (Cano et al., 1993), it has been demonstrated that in respiratory samples of some subjects without signs and symptoms of pneumonia, can be detected low levels of Pneumocystis DNA that likely represent colonization (Wissmann et al., 2010). Other terms that have been used include "carriage", "subclinical infection" and "asymptomatic infection" (Peterson et al., 2005).

\footnotetext{
* Instituto de Biomedicina de Sevilla, Hospital Universitario Virgen del Rocío/CSIC/Universidad de Sevilla, Seville, Spain.

** Servicio de Medicina Interna Hospital Universitario Virgen del Rocío, Seville, Spain.

**** CIBER en Epidemiología y Salud Pública, Hospital Universitario Virgen del Rocío, Seville, Spain.

Correspondence: Sonia Gutiérrez, Department of Internal Medicine, Virgen del Rocío University Hospital, Avda Manuel Siurot s/n, 41013 Seville, Spain.

Tel.: 34955014278 - Fax: 34955013292.

E-mail: anisoguri@hotmail.com
}

Résumé : COLONISATION PAR PNEUMOCYSTIS JIROVECII D'AFFECTIONS PULMONAIRES CHRONIQUES

Pneumocystis jirovecii est un agent de pneumonie chez les sujets immunodéprimés. Des faibles taux d'ADN de Pneumocystis peuvent cependant être détectés chez des patients sans pneumonie; ils correspondraient à des situations de colonisation. Plusieurs études développées chez l'animal et chez l'homme ont montré que la colonisation par Pneumocystis peut induire chez l'hôte des réponses locale et systémique. Comme la colonisation peut être observée chez des patients atteints d'affections pulmonaires chroniques, il a été suggéré que P. jirovecii pourrait jouer un rôle dans la physiopathologie et l'aggravation de ces maladies. Dans cette revue, nous examinons la colonisation par P. jirovecii chez des patients atteints de maladies pulmonaires chroniques comme la bronchopneumopathie chronique obstructive, les fibroses pulmonaires interstitielles, la fibrose kystique et le cancer du poumon.

MOTS-CLÉS : Pneumocystis jirovecii, colonisation, broncho-pneumopathie chronique.

The first evidence reported of $P$. jirovecii colonization in patients with chronic bronchial diseases without immunosuppression was observed by using immunofluorescence with monoclonal antibodies and standard stains. It was found that $10 \%$ of patients was colonized (Calderón et al., 1996). Current detection of Pneumocystis colonization has been greatly facilitated by the development of sensitive molecular techniques, such as polymerase chain reaction (PCR) (Calderón et al., 2010). The rate of $P$. jirovecii colonization reported in chronic pulmonary diseases is diverse as a result of the used different sampling or detection procedures and the area where the study was performed (see Morris et al., 2008b for review), since P. jirovecii infection is apparently linked with environmental factors and probably there are low and high-risk geographical areas (Varela et al., 2004).

It has been reported that Pneumocystis induce in animals models alveolar macrophage activation, elevation of proinflammatory interleukins, changes in lung surfactant, type I pneumocyte degenerative changes, type II pneumocyte reparatory hypertrophy, alterations in alveolus-capillary permeability, diffuse alveolar damage and lung fibrosis (Prévost et al., 1998; Rice et al., 1993; Thomas et al., 2007). In addition, a study using a culture system revealed that Pneumocystis 
major surface glycoprotein induces interleukin (IL)-8 and monocyte chemoattractant protein-1 release from a human alveolar epithelial cell line (Benfield et al., 1999). Besides, it has been recently demonstrated that colonized patients with chronic obstructive pulmonary disease (COPD) have higher systemic proinflammatory cytokine levels than do noncolonized patients (Calderón et al., 2007). These data suggest that Pneumocystis could play a role in the progression of chronic pulmonary diseases.

On the other hand, colonized patients can act as a reservoir and source of infection for susceptible subjects. In fact, the first molecular evidence that transmission of $P$. jirovecii from colonized immunocompetent carriers to susceptible subjects may occur has been recently provided (Rivero et al., 2008). What's is more, colonized individuals could represent a reservoir to $P$. jirovecii strains with dihydropteroate synthase (DHPS) gene mutations, potentially related with sulfadrugs resistance (Stein et al., 2004). In this sense, the finding of Pneumocystis DHPS gene mutations in two colonized patients with chronic bronchitis, who were not previously exposed to sulfa drugs (Calderón et al., 2004), suggests either possible occurrence of spontaneous mutations or, most probably, transmission of mutant strains from HIV-infected patients (frequently submitted to sulfa prophylaxis).

In this report we revise our current knowledge about $P$. jirovecii colonization in four major chronic lung diseases: COPD, interstitial lung diseases (ILDs), cystic fibrosis (CF) and lung cancer.

\section{CHRONIC OBSTRUCTIVE PULMONARY DISEASE}

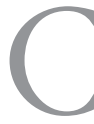
OPD is a major cause of illness, death, and the use of health care resources globally. The disease causes approximately 2.75 million deaths annually, and the number is projected to increase. At present, it is the $4^{\text {th }}$ most common cause of death among adults, and it is estimated to rank $3^{\text {rd }}$ by 2020 (Chapman et al., 2006; Lopez et al., 2006). COPD is a slowly progressive condition characterized by airflow limitation that is not fully reversible. The airflow limitation is associated with a chronic inflammatory response in both airways and lung parenchyma (MacNee, 2005). Smoking is considered to be the major cause of COPD, but only a small portion of all smokers develops the disease. It has been hypothesized that cofactors, as P. jirovecii colonization, may play a role in COPD development (Morris et al., 2008a). Additionally, smoking would be a risk factor for $P$. jirovecii colonization in both HIV- infected individuals (Morris et al., 2004a) and subjects with chronic pulmonary diseases (Vidal et al., 2006). Actually, cigarette smoking results in impaired mucociliary clearance, which could facilitate $P$. jirovecii colonization. In short, Pneumocystis lower respiratory tract colonization, together with smoking, could be a cofactor that increase or maintain inflammatory response, accelerating COPD progression. The rate of P. jirovecii colonization reported among patients with COPD is usually high. It shows however significant differences (16 to $55 \%$ ) that suggest major geographical disparities in $P$. jirovecii epidemiology (Calderón et al., 2007; Nevez et al., 2006). Interestingly, among the COPD patients from a same geographical area $P$. jirovecii colonization is more prevalent in those with severe COPD (Morris et al., 2004b).

$\beta$-glucans are major structural components of cyst wall of Pneumocystis (Lebrón et al., 2003). $\beta$-glucans potently activate alveolar macrophages to release pro-inflammatory cytokines and chemokines through

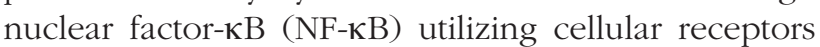
and signalling pathways distinct from bacterial lipopolysaccharide. $\beta$-glucans induce both cytokine generation and associated neutrophilic lung inflammation. In addition to Pneumocystis clearance, macrophages also strongly initiate inflammatory responses in the lung following interactions with $\beta$-glucan components of the organism, including secretion of tumor necrosis factor- $\alpha$ (TNF- $\alpha$ ), IL-6, IL-8, macrophage inflammatory protein-2, eicosanoid metabolites, and reactive oxidant species (Lebrón et al., 2003). These exuberant host inflammatory responses, though necessary for clearance of infection, further promote lung injury resulting in airspace inflammation and excessive morbidity. The pulmonary inflammatory response against Pneumocystis resembles that associated with COPD and could therefore contribute to the pathogenesis of airway and parenchyma damage in subjects with this disease (Morris et al., 2008a).

An interesting study showed that Pneumocystis colonization correlates with degree of airway obstruction independent of smoking history (Morris et al., 2004b). This study did not prove causality, but it strongly suggests that Pneumocystis colonization affects COPD progression. In this sense, patients with COPD colonized by $P$. jirovecii were found to develop a higher systemic inflammatory response (increased levels of several circulating cytokines and acute-phase reactants including IL-8, IL- 6 and TNF- $\alpha$ ) than do noncolonized patients (Calderón et al., 2007). In COPD patients, systemic inflammatory response has been linked to weight loss, muscle wasting and accelerate decrease in lung function (Gan et al., 2004). As a cause of systemic inflammatory response, Pneumocystis colonization could therefore play a role in the pathophysiology of COPD. 


\section{INTERSTITIAL LUNG DISEASES}

T LDs are a heterogeneous group of disorders of the lower respiratory tract in which injury to the lung parenchyma leads to a cascade of inflammatory and immune processes that cause lung fibrosis. The exact mechanism by which connective tissue proliferation occurs in some cases is unknown, although infectious agents have been implicated in the pathogenesis of ILDs (Egan et al., 1997, du Bois et al., 2003). In this way, it has been suggested that pulmonary inflammation, together with the adaptive immune response triggered by alveolar injury caused by Pneumocystis, could play a role in the pathogenesis of ILDs and in the progression of the disease to fibrosis. The rate of $P$. jirovecii colonization in patients with ILDs ranged from 30 to $34 \%$ (Vidal et al., 2006; Martín-Juan et al., 2008; Shimizu et al., 2009) and it is similar among different kind of ILDs (Martín-Juan et al., 2008) (Table I).

Interestingly, in a large study carried out in 240 patients with ILDS (Martín-Juan et al., 2008), patients with ILDs who were carriers of $P$. jirovecii showed a significant higher peripheral blood total leukocyte and eosinophil levels compare to non-carriers. Also, the differential cell counts in the bronchoalveolar lavage fluid revealed a low $\mathrm{CD}^{4} / \mathrm{CD}^{8}$ ratio in carrier patients, mainly because of an increased $\mathrm{CD}^{8+} \mathrm{T}$-cell count, although the differences did not reach statistical significance. This finding suggests that Pneumocystis colonization may be related to an exacerbation of these diseases. Further studies are needed in order to confirm the clinical significance of these findings.

\section{CYSTIC FIBROSIS}

C $\mathrm{F}$ is the most common serious hereditary disorder in the Caucasian populations. It is caused by several mutations in the CF transmembrane conductance regulator gene that map on the large arm of chromosome 7 (7q31.2) and encodes a chloride channel involved in electrolytic exchanges through the plasma membrane, leading to a defect in the mucociliary clearance and a thickness of the bronchial mucus (Rowe et al., 2005). Several organs are affected in this disease and pulmonary damage is the most serious clinical problem. An important factor that contributes to the development of pulmonary disease in patients with CF is persistent infection by opportunistic pathogens, mainly Pseudomonas aeruginosa, Staphylococcus aureus, Haemophilus influenza and Burkbolderia cepacia (Rowe et al., 2005).

Recent researches indicate that a wide range of fungi can colonize the respiratory tract of patients with CF. Aspergillus fumigatus is the main fungus involved in fungal-related CF complication, however it is not the fungal infection itself which is mainly responsible for respiratory failure, instead the fungus grows in the upper respiratory way of CF patients, where it provokes repeated immune stimulation, such mechanism leads to Allergic bronchopulmonary aspergillosis (ABPA), a chronic hypersensitivity condition that can lead to morbidity and ultimately to respiratory failure (Antunes et al., 2010).

Only a few published studies carried out in Europe have evaluated the prevalence of Pneumocystis colonization in patients with $\mathrm{CF}$, reporting ranges from $1.3 \%$
Interstitial lung diseases

Idiopathic pulmonary fibrosis

Fibrosing lung disease associated with connective tissue disease Sarcoidosis

Cryptogenic organizing pneumonia

Diffuse alveolar haemorrhage
Patients with $P$. jirovecii colonization detected by studied colonization detected by conventional and immuno-

(n) molecular techniques (\%) fluorescence staining (\%)

$\begin{array}{lcl}69 & 22(31.8 \%) & 4(5.7 \%) \\ 38 & 13(34.2 \%) & 2(5.2 \%) \\ 35 & 10(28.5 \%) & 2(5.7 \%) \\ 31 & 9(29 \%) & 1(3.2 \%) \\ 20 & 8(40 \%) & 2(10 \%)\end{array}$

Modified from Martín-Juan et al., 2008

Table I. - Prevalence of Pneumocystis colonization in individuals with interstitial lung diseases from Andalucía (Spain).

\begin{tabular}{lcccc}
\hline \multicolumn{1}{c}{ Country } & $\begin{array}{c}\text { Number } \\
\text { of patients }\end{array}$ & $\begin{array}{c}\text { Prevalence of Pneumocystis } \\
\text { colonization (\%) }\end{array}$ & $\begin{array}{c}\text { Median age } \\
\text { (years) }\end{array}$ & $\begin{array}{c}\text { Chemoprophylaxis with } \\
\text { co-trimoxazole (\%) }\end{array}$ \\
\hline Germany & 95 & $7.4 \%$ & 23.2 & Sing et al., 2001 \\
Spain & 88 & $21.6 \%$ & 15.8 & $2.3 \%$ \\
France & 76 & $1.3 \%$ & 18.5 & $39.5 \%$ \\
\hline
\end{tabular}

Table II. - Prevalence of Pneumocystis jirovecii colonization detected by using molecular methods among patients with cystic fibrosis 
to $21.6 \%$ (Table II) (Sing et al., 2001; Respaldiza et al., 2005; Nevez et al., 2010). These differences in colonization rates could be related with differences in use of chemoprophylaxis with sulfa-drugs to prevent bacterial infections among the CF patients (Sing et al., 2001; Respaldiza et al., 2005; Gal et al., 2010). However, they could also be due to differences in population density, and in HIV infection or PCP incidence (Gal et al., 2010). On the other hand, several studies have shown seasonal changes of $\mathrm{PcP}$ incidence that seem to be associated with climate factors (Lubis et al., 2003; Varela et al., 2004; Sing et al., 2009). In this sense, the higher $P$. jirovecii colonization rates observed in patients with CF from Southern Europe than in patients from Northern Europe could be related with climate factors (Sing et al., 2001; Respaldiza et al., 2005; Gal et al., 2010).

Pneumocystis colonization does not appear to be a risk factor for subsequent $\mathrm{PCP}$ in $\mathrm{CF}$ patients, probably because the immune status of these patients is usually enough to control the colonization to pneumonia shift (Sing et al., 2001; Respaldiza et al., 2005; Montes-Cano et al., 2007). However, even without deep immunosuppression, in chronic lung conditions Pneumocystis colonization could provoke mild or moderate respiratory illness, with the pathogen acting as a co-morbidity factor that may stimulate pulmonary inflammation and may play a pathogenic role (Calderón et al., 2007; Morris et al., 2008b). Thus, it would be hypothesized that $P$. jirovecii colonization provokes airflow obstruction and inflammatory response in $\mathrm{CF}$ patients. However, to our knowledge, no evidence supporting this hypothesis was provided till now. In other words, it has not yet been established whether $P$. jirovecii colonization could have a role in worsening the natural course of $\mathrm{CF}$.

On the other hand, our knowledge of how P. jirovecii interact with pathogenic bacteria in the respiratory tract of patients with $\mathrm{CF}$ is completely unknown but this interaction could have some impact in the pathophysiology of CF. In this sense, a potential antagonistic relation among $P$. jirovecii colonization and bacterial microbiota has been recently reported in the respiratory tract of patients with idiopathic interstitial pneumonia (Friaza et al., 2010).

\section{LUNG CANCER}

-obacco smoking is the most important but not the only risk factor in lung carcinoma. The role of infectious agents in the development of human tumours was not demonstrated until recently (Kuper et al., 2000). Actually, it is estimated that $15 \%$ of all human cancers worldwide have an infectious origin (Pisani et al., 1997). Recently, it has been reported the first evidence of an association between small cell lung carcinoma and the presence of $P$. jirovecii colonization. In this study, in all the examined samples of small cell lung carcinoma $P$. jirovecii was detected (it was not found in metastases) (de la Horra et al., 2004). While the nature of this association is unclear, it nevertheless constitutes an important finding and open a new field for research since it is unknown either the $P$. jirovecii colonization is specifically facilitated by this tumour or induces the development of this type of neoplasm in combination with other factors.

\section{CONCLUSIONS}

T There is a high prevalence of $P$. jirovecii colonization in patients with chronic pulmonary diseases (Calderón, 2009). Data from different studies suggest a potential role of $P$. jirovecii in the pathophysiology of chronic pulmonary diseases through inducing inflammatory changes with chronic lung injury, but also interacting with other agents as tobacco or pathogenic bacteria (Calderón et al., 2007; Morris et al., 2008a; Christensen et al., 2008; Friaza et al., 2010). Understanding the role of P. jirovecii colonization in patients with chronic lung diseases may help us identify a novel, treatable pathogenic agent.

On the other hand, $P$. jirovecii colonization in patients with chronic pulmonary diseases could represent a problem for public health since colonized patients could act as a major reservoir and source of infection for susceptible subjects (Calderón, 2009; Wissmann et al., 2010). In the future, advances as real time PCR could enhanced the sensitivity of Pneumocystis DNA detection and to make research on Pneumocystis colonization epidemiology much easier. In this way, the role of non invasive marker serum as $\beta$-glucan levels in colonized patients should be explored (Krajicek et al., 2008). Further investigation is need to better define the epidemiology and the role of $P$. jirovecii colonization in the natural course of chronic pulmonary diseases and to determine the exact mechanism of its effects.

\section{ACKNOWLEDGEMENTS}

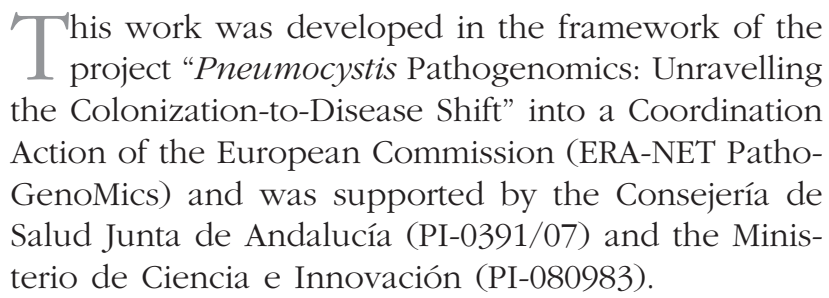

This work was developed in the framework of the I project "Pneumocystis Pathogenomics: Unravelling the Colonization-to-Disease Shift" into a Coordination Action of the European Commission (ERA-NET PathoGenoMics) and was supported by the Consejería de terio de Ciencia e Innovación (PI-080983). 


\section{REFERENCES}

Antunes J., Fernandes A., Borrego L.M., Leiria-Pinto P. \& Cavaco J. Cystic fibrosis, atopy, asthma and ABPA. Allergol Immunopathol, 2010, 38, 278-284.

Benfield T.L., Lundgren B., Shelhamer J.H. \& Lundgren J.D. Pneumocystis carinii major surface glycoprotein induces interleukin-8 and monocyte chemoattractant protein-I release from a human alveolar epithelial cell line. European Journal of Clinical Investigation, 1999, 29, 717-22.

Calderón E.J., Regordan C., Medrano F.J., Ollero M. \& VARELA J.M. Pneumocystis carinii infection in patients with chronic bronchial disease. Lancet, 1996, 347, 977.

Calderón E., de la Horra C., Medrano F.J., López-Suárez A., Montes-Cano M.A., Respaldiza N., Elvira-González J., Martín-Juan J., Bascuñana A. \& Varela J.M. Pneumocystis jiroveci isolates with dihydropteroate synthase mutations in patients with chronic bronchitis. European Journal of Clinical Microbiology \& Infectious Diseases, 2004, 23, 545-549.

Calderón E.J, Rivero L., Respaldiza N., Morilla R., MontesCano M.A., Friaza V., Muñoz-Lobato F., Varela J.M., Medrano F.J. \& DE la Horra C. Systemic inflammation in patients with chronic obstructive pulmonary disease who are colonized with Pneumocystis jiroveci. Clinical Infectious Diseases, 2007, 45, e17-e19.

CALderón E.J. Epidemiology of Pneumocystis infection in Human. Journal de Mycologie Médicale, 2009, 19, 270-275.

Calderón E.J., Gutiérrez-Rivero S., Durand-Joly I. \& DeiCas E. Pneumocystis infection in humans: diagnosis and treatment. Expert Review of Anti-infective Therapy, 2010, 8, 259-262.

Cano S., Capote F., Pereira A., Calderón E. \& Castillo J. Pneumocystis carinii pneumonia in patients without predisposing illnesses. Acute episode and follow-up of five cases. Chest, 1993, 104, 376-381.

Chapman K.R., Mannino D.M., Soriano J.B., Vermeire P.A., Buist A.S., Thun M.J., Connell C., Jemal A., Lee T.A., Miravitlles M., Aldington S. \& Beasley R. Epidemiology and costs of chronic obstructive pulmonary disease. European Respiratory Journal, 2006, 27, 188-207.

Christensen P.J., Preston A.M., Ling T., Du M., Fields W.B., Curtis J.L. \& Beck J.M. Pneumocystis murina infection and cigarette smoke exposure interact to cause increased organism burden, development of airspace enlargement, and pulmonary inflammation in mice. Infection and Immunity, 2008, 76, 3481-3490.

de la Horra C., Varela J.M., Fernández-Alonso J., Medrano F.J., Respaldiza N., Montes-Cano M.A. \& Calderón E.J. Association between human-Pneumocystis infection and small-cell lung carcinoma. European Journal of Clinical Investigation, 2004, 34, 229-235.

du Bois R.M., Goh N., McGrath D. \& Culuinan P. Is there a role for microorganisms in the pathogenesis of sarcoidosis? Journal of Internal Medicine, 2003, 253, 4-17.

Egan J.J., Woodcock A.A. \& Stewart J.P. Viruses and idiopathic pulmonary fibrosis. European Respiratory Journal, 1997, 10, 1433-1437.
Friaza V., de la Horra C., Rodríguez-Domínguez M.J., MartínJuan J., Cantón R., Calderón E.J. \& del Campo R. Metagenomic analysis of bronchoalveolar lavage samples from patients with idiopathic interstitial pneumonia and its antagonic relation with Pneumocystis jirovecii colonization. Journal of Microbiological Methods, 2010, 82, 98-101.

Gal S.L., Héry-Arnaud G., Ramel S., Virmaux M., Damiani C., Totet A. \& Nevez G. Pneumocystis jirovecii and cystic fibrosis in France. Scandinavian Journal of Infectious Diseases, 2010, 42, 225-227.

Gan W.Q., Man S.F.P., Senthilselvan A. \& Sin D.D. Association between chronic obstructive pulmonary disease and systemic inflammation: a systematic review and a metaanalysis. Thorax, 2004, 59, 574-580.

Krajicek B.J., Limper A.H. \& Thomas C.F. Jr. Advances in the biology, pathogenesis and identification of Pneumocystis pneumonia. Current Opinion in Pulmonary Medicine, 2008, 14, 228-234.

Kuper H., Adami H.O. \& Trichopoulos D. Infections as a major preventable cause of human cancer. Journal of Internal Medicine, 2000, 248, 171-183.

Lebron F., Vassallo R., Puri V. \& Limper H. Pneumocystis carinii cell wall $\beta$-glucans initiate macrophage inflammatory responses through NFKB activation. The Journal of Biological Chemistry, 2003, 278, 25001-25008.

Lopez A.D., Shibuya K., Rao C., Mathers C.D., Hansell A.L., Held L.S., SChmid V. \& Buist S. Chronic obstructive pulmonary disease: current burden and future projections. European Respirory Journal, 2006, 27, 397-412.

Lubis N., Baylis D., Short A., Stebbing J., Teague A., Portsmouth S., Bower M., Nelson M. \& Gazzard B. Prospective cohort study showing changes in the monthly incidence of Pneumocystis carinii pneumonia. Postgraduate Medical Journal, 2003, 79, 164-166.

Martín-Juan J., Gómez-Izquierdo L., Lara L., RodríguezBecerra E., de la Horra C., Montes-Cano M.A., Respaldiza N. \& CALDERón E. Factores relacionados con la infección por Pneumocystis jirovecii en pacientes con enfermedad pulmonar intersticial difusa. Neumosur, 2008, 20, 65-73.

MacNeE W. Pathogenesis of chronic obstructive pulmonary disease. Proceedings of the American Thoracic Society, 2005, 2, 258-266.

Montes-Cano M.A., de la Horra C., Dapena F.J., Mateos I., Friaza V., Respaldiza N., Muñoz-Lobato F., Medrano F.J., Calderón E.J. \& Varela J.M. Dynamic colonisation by different Pneumocystis jirovecii genotypes in cystic fibrosis patients. Clinical Microbiology and Infection, 2007, 13, 1008-1011.

Morris A., Kingsley L.A., Groner G., Lebedeva I.P., Beard C.B. \& Norris K.A. Prevalence and clinical predictors of Pneumocystis colonization among HIV-infected men. AIDS, 2004a, 18, 793-798.

Morris A., Sciurba F.C., Lebedeva I.P., Githaiga A., Elliott W.M., Hogg J.C., Huang L. \& Norris K.A. Association of chronic obstructive pulmonary disease severity and Pneumocystis colonization. American Journal of Respiratory and Critical Care Medicine, 2004b, 170, 408-413.

Morris A., Sciurba F.C. \& Norris K.A. Pneumocystis: a novel pathogen in chronic obstructive pulmonary disease? 
COPD: Journal of Chronic Obstructive Pulmonary Disease, 2008a, 5, 43-51.

Morris A., Wei K., Afshar K. \& Huang L. Epidemiology and clinical significance of Pneumocystis colonization. The Journal of Infectious Diseases, 2008b, 197, 10-17.

Nevez G., Magois E., Duwat H., Goullleux V., Jounieaux V. \& Toтет A. Apparent absence of Pneumocystis jirovecii in healthy subjects. Clinical Infectious Diseases, 2006, 42, e99-e101.

Peterson J.C. \& Cushion M.T. Pneumocystis: not just pneumonia. Current Opinion in Microbiology, 2005, 8, 393398.

Pisani P., Parkin D.M., Muñoz N. \& Ferlay J. Cancer and infection: estimates of the attributable fraction in 1990. Cancer Epidemiology, Biomarkers \& Prevention, 1997, 6, 387-400.

Prévost M.C., Escamilla R., Aliouat E.M., Ceré N., Coudert P. \& DeI-CAS E. Pneumocystosis pathophysiology. FEMS Immunology and Medical Microbiology, 1998, 28, 123128.

Respaldiza N., Montes-Cano M.A., Dapena F.J., de la Horra C., Mateos I., Medrano F.J., Calderón E. \& Varela J.M. Prevalence of colonisation and genotypic characterisation of Pneumocystis jirovecii among cystic fibrosis patients in Spain. Clinical Microbiology and Infection, 2005, 11, 1012-1015.

Rice W.R., Singleton F.M., Linke M.J. \& Walzer P.D. Regulation of surfactant phosphatidilcholine secretion from alveolar type II cells during Pneumocystis carinii pneumonia in the rat. The Journal of Clinical Investigation, 1993, 92 (6), 2778-2782.

Rivero L., de la Horra C., Montes-Cano M.A., RodríguezHerrera A., Respaldiza N., Friaza V., Morilla R., Gutiérrez S., Varela J.M., Medrano F.J. \& Calderón E.J. Pneumocystis jirovecii transmission from immunocompetent carriers to infant. Emerging Infectious Diseases, 2008, 14, 11161118 .

Rowe S.M., Miller S., Sorscher E.J. Cystic fibrosis. The New England Journal of Medicine, 2005, 352, 1992-2001.

Shimizu Y., Sunaga N., Dobashi K., Fueki M., Fueki N., Makino S. \& MORI M. Serum markers in interstitial pneumonia with and without Pneumocystis jirovecii colonization: a prospective study. BMC Infectious Diseases, 2009, 9, 47.

Sing A., Geiger A.M., Hogardt M. \& Heeseman J. Pneumocystis carinii carriage among cystic fibrosis patients, as detected by nested PCR. Journal of Clinical Microbiology, 2001, 39, 2717-2718.

Sing A., Schmoldt S., Laubender R.P., Heesemann J., Sing D. \& WILDNER M. Seasonal variation of Pneumocystis jirovecii infection: analysis of underlying climatic factors. Clinical Microbiology and Infection, 2009, 15, 957-960.

Stein C.R., Poole C., Kazanjian P. \& Meshnick S.R. Sulfa use, dihydropteroate synthase mutations, and Pneumocystis jirovecii pneumonia. Emerging Infectious Diseases, 2004, 10, 1760-1765.

Thomas C.F. \& Limper A.H. Current insights into the biology and pathogenesis of Pneumocystis pneumonia. Nature Reviews Microbiology, 2007, 5, 298-308.
Varela J.M., Regordán C., Medrano F.J., Respaldiza N., de la Horra C., Montes-Cano M.A. \& Calderón E.J. Climatic factors and Pneumocystis jirovecii infection in southern Spain. Clinical Microbiology and Infection, 2004, 10, 770-772.

Vidal S., de la Horra C., Martín J., Montes-Cano M.A., Rodríguez E., Respaldiza N., Rodríguez F., Varela J.M., Medrano F.J. \& Calderón E.J. Pneumocystis jirovecii colonisation in patients with interstitial lung disease. Clinical Microbiology and Infection, 2006, 12, 231-235.

Wissmann G., Morilla R., Friaza V., Calderón E. \& Varela J.M. El ser humano como reservorio de Pneumocystis. Enfermedades Infecciosas y Microbiología Clínica, 2010, $28,38-43$.

Received on June $30^{\text {th }}, 2010$ Accepted on October $31^{\text {th }}, 2010$ 